\title{
Burnout Syndrome at Work by Doctors Employed at Emergency Center of Clinical Center of Serbia
}

\author{
Aleksandra M. Bukumirovicic ${ }^{1}$ Sanja D. Totić-Poznanović ${ }^{2,7}$, \\ Ljiljana N. Marković-Denić3 ${ }^{3}$ Zoran M. Bukumirić ${ }^{4}$, \\ Aleksandra N. Vlačić ${ }^{5}$, Vladimir S. $\operatorname{Radak}^{1}$, Ratko M. Lasica ${ }^{6,7}$, \\ Ana D. Šijački ${ }^{1,7}$ \\ ${ }^{1}$ Center for Research, Education and Human Resources, Clinical Center of Serbia, Belgrade, \\ Serbia \\ ${ }^{2}$ Clinic for psychiatry, Clinical Center of Serbia, Belgrade, Serbia \\ ${ }^{3}$ Institute of Epidemiology, Medical Faculty University of Belgrade, Belgrade, Serbia \\ ${ }^{4}$ Institute for Medical Statistics and Informatics, Medical Faculty University of Belgrade, Bel- \\ grade, Serbia \\ ${ }^{5}$ Department of Biomedicine, Ministry of Health of the Republic of Serbia, Belgrade, Serbia \\ ${ }^{6}$ Clinic for Cardiology, Clinical Center of Serbia, Belgrade, Serbia \\ ${ }^{7}$ Medical Faculty University of Belgrade, Belgrade, Serbia
}

\section{SUMMARY}

Introduction: Burnout is often used to describe the state or mental process similar to a firearm after shooting or extinguishing spent candles.

Aim: The objective of the present research was to value the relation between the socio-demographic data with the presence of the burnout-syndrome in the investigated subjects.

Methods: The research was done as cross-sectional study, during May-June 2017 and February-March 2018 at the Emergency Center of Clinical Centre of Serbia. Medical doctors with full work-time who accepted kindly the anonymous pull were evaluated. To precede the measure of subjective perception of health, the Serbian version of Maslach Burnout Inventory-Human Services Survey (MBI-HSS) was used.

Results: At the evaluation of the level of burnout (MBI-HSS) in Serbian language, 76 investigated doctors of the Emergency Center completed the inquiry. 35-44 years old category was the most representative with $40.8 \%$ respondents. Respondents most often live in community were $52.6 \%$ of all and $48.7 \%$ have children. $75 \%$ respondents showed a low level of depersonalization. There was a significant negative correlation between the years of service and level of depersonalization. Both genders $(50.0 \%$ respondents) showed a high degree of lack of personal achievements, female $55.3 \%$ slightly higher than male respondents $44.7 \%$. High emotional exhaustion was present in $85.5 \%$ and showed no significant difference in the degree of emotional exhaustion in relation to gender. A significant difference was observed by respondents who do not have children, they are subjected to higher emotional exhaustion.

Conclusion: Burnout should be studded by a team composed of experts (psychiatry, occupational medicine and epidemiology) in order to determine the degree to which 
burnout is related to work and how to prevent and mitigate it. Respondents with lower years of service have a higher degree of depersonalization and respondents without children are subjected to higher emotional exhaustion.

Keywords: Syndrome Burnout, stress, medical doctors

\section{INTRODUCTION}

The term burnout is an expression from the 1970th originated by the American psychologist Freudenberger [1,2]. The term is used in order to describe the consequences of stress and high ideals of people who worked in the "helper" professions [3]. According to Maslash, one of the leading experts in this area, burnout syndrome is a reaction to chronic emotional and cynicism (negative or overly personal reaction to different aspects of the job) and inefficiency [4]. Maslash first published Burnout Syndrome Questionnaire called Maslach Burnout Inventory (MBI), which is still in use [4].

A large number of research have imposed the need to look at this phenomenon in other profiles, not just those from the socalled helpless - service activities, as initially $[3,5]$. It has been shown that the occurrence of this syndrome can be invoked by workers of all professions, employed in administrative affairs as well as workers in productive activities [6,7] and can be recognized even before employment: in students as so-called "student burnout syndrome" $[7,8]$. Etiopathogenesis of the burnout syndrome is complex but is generally considered to be extended "negative stress" as key factor in its formation, whereby the characteristics of individuals and the impossibility of successful overcoming also play an important role. Other important pathogenic factors can be identified as "slavery to daily routine" or "disappointment due to excessive expectations" [3,7]. Vuković et al 2017, pointed out negative correlation between work environment and efficiency satisfaction of healthcare professionals, and job pressure due to anxiety and chronic stress presence at work [9]. Burnout has long been defined as a state of progressive loss of idealism, energy, and meaning of their work. Workers perceive it as a reaction to chronic sources of stress at work, with already defined stages in its evolution (enthusiasm, stagnation, frustration, apathy). As a medi- cal condition burnout has not yet been clearly defined $[3,5,10]$. Recognizing this condition is a need in the society and is reflected in the European Union's Decree on Health and Safety at Work, whose provisions may also apply to psychosocial characteristics of work (89/391/ EEC) [11].

\section{AIM}

The aim of this study was to assess the relation of sociodemographic variables with the presence of burnout in the study population of physicians.

\section{METHODS}

Burnout syndrome manifests itself differently, occurs more frequently in emergency and complex medical interventions and leads to discontent at the workplace, especially in young doctors without experience and with great ambitions. The greater the degree of expressed exhaustion syndrome with doctors without specialization, families and bad financial situation. This paper is part of a non-commercial, retrospective, epidemiological study in the period May-June 2017 and FebruaryMarch 2018 at the Emergency Center of the Clinical Center of Serbia (EC CCS). Terms used in consideration of specialist is a qualified physician with a completed specialization; community life is considered to life in any type of community, whether married or in a domestic partnership, family affiliation occurs if the respondent contributes to the community's finances For the purpose of this research, a specially designed questionnaire was used which, in addition to the sociodemographic and economic characteristics of the examinees, observes certain behavioral characteristics [12] and a questionnaire for the assessment of burnout syndrome at work for employees in direct contact with people: the Maslach Burn- 


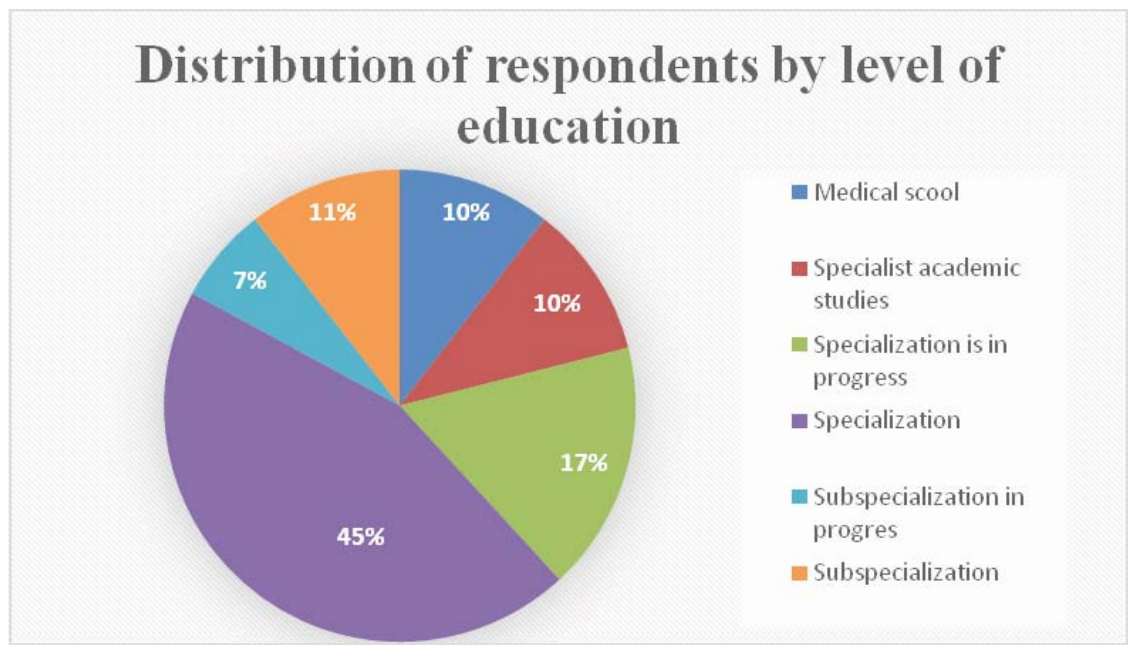

out Inventory-Human Services Survey (MBIHSS) [12]. MBI-HSS examines the psychological effects of three levels of burnout syndrome (low / moderate / high): emotional exhaustion, depersonalization and personal (non) realization $[13,14]$. The rights to use the questionnaire were purchased in Serbian.

\section{Statistical methods}

From descriptive statistical methods were used measures of central tendency (mean, median), a measure of variability (standard deviation) and the relative numbers (frequency, percent). Methods for testing statistical hypotheses were used: Cronbach a reliability, Fisher Exact Probability Test or Pearson's chi-squared test, Kruskal-Wallis test and Spearman's coefficient of rank correlation. Statistical hypotheses were tested at the level of statistical significance (alpha level) of 0.05 .

\section{RESULTS}

\section{Description of the population}

In accordance with good clinical practice, physicians-respondents gave signed consent and filled in the questionnaire by themselves. 76 different specialists answered correctly to the examination, male $38(50.0 \%)$ and female the same number. The age structure of the respondents in the most representative category (35-44 years) was 31 (40.8\%). Respondents involved in the research live most often in a community (married or domestic partnership) $40(52.6 \%)$ of respondents and 37 (48.7\%) had children. The financial burden of the whole family fell to 35 (46.1\%) respondents. The more respondents had 6-20 years of service. In Figure 1 we showed the distribution of respondents according to the degree of education.

\section{Survey Analysis - Maslach Burnout Inven- tory MBI-HSS}

The reliability of the MBI-HS instrument was good, the questionnaire had an adequate level of internal consistency (Cronbach $\alpha=0.832$ ). The depersonalization median was $4(0-20)$, personal accomplishment median was 38.50 (0-48) and emotional exhaustion median was 32 (14-41).

The low level of depersonalization of most respondents by $75 \%$, depersonalization was equally present in both genders. There was a statistically significant negative correlation between the working life and the degree of depression ( $r s=-0.333 ; p=0.028$ ). Respondents with less years of service had a higher degree of
Figure 1. Distribution of respondents by level of education

\begin{tabular}{|c|c|c|c|c|c|c|c|c|c|c|}
\hline & \multicolumn{3}{|c|}{$\begin{array}{c}\text { Level of } \\
\text { depersonalization (\%) }\end{array}$} & \multicolumn{3}{|c|}{$\begin{array}{l}\text { Level of personal } \\
\text { achievement (\%) }\end{array}$} & \multicolumn{3}{|c|}{$\begin{array}{l}\text { Level of emotional } \\
\text { exhaustion (\%) }\end{array}$} \\
\hline & & Low & Moderate & High & Low & Moderate & High & Low & Moderate & High \\
\hline \multirow{4}{*}{$\begin{array}{l}\text { Age range } \\
\text { respondents } \\
\text { in years }\end{array}$} & $25-34$ & 17.5 & 50.0 & 40.0 & 26.7 & 21.7 & 26.3 & 33.3 & 33.3 & 33.3 \\
\hline & $35-44$ & 45.6 & 14.3 & 60.0 & 46.7 & 34.8 & 42.1 & 0.0 & 0.0 & 0.0 \\
\hline & $45-54$ & 28.1 & 28.6 & 0.0 & 20.0 & 30.4 & 26,3 & 27.7 & 27.7 & 27.7 \\
\hline & $\geq 55$ & 8.8 & 7.1 & 0.0 & 6.7 & 13.0 & 5.3 & 0.0 & 0.0 & 0.0 \\
\hline
\end{tabular}

Table 1. Distribution of respondents for age according to the degree of depersonalization, and personal achievement degree of emotional exhaustion 
Figure 2. Distribution of emotional exhaustion of respondents in relation to years of work experience

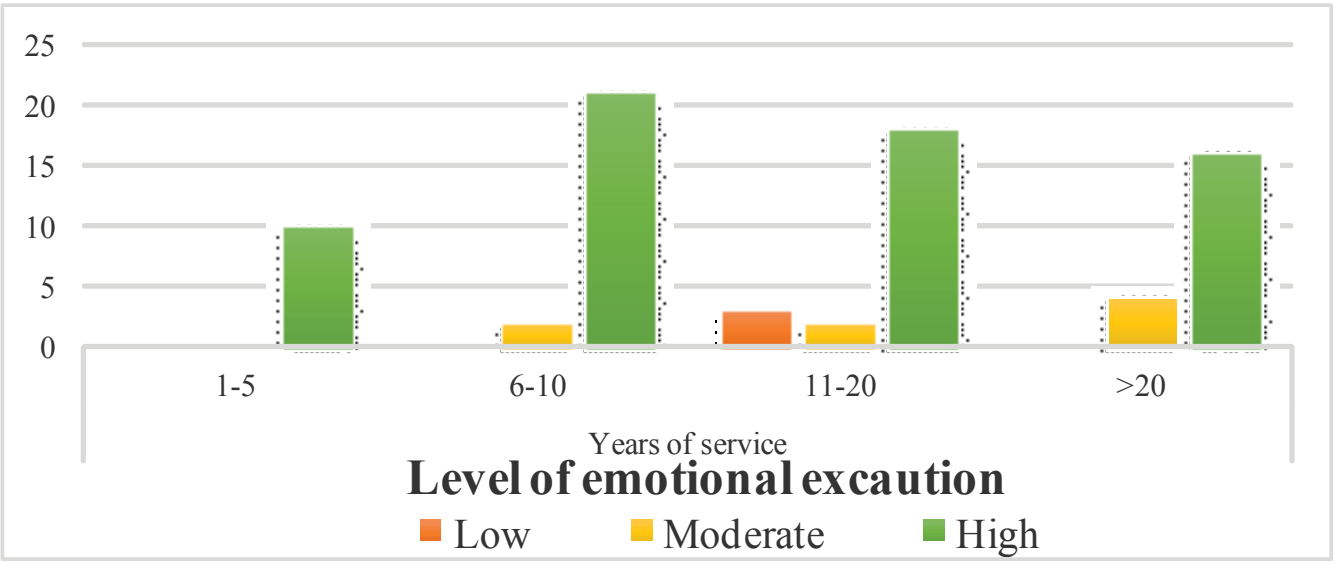

depersonalization.

Both genders showed a high degree of lack of personal achievements 38 (50.0\%) respondents, female $21(55.3 \%)$ slightly higher than male respondents 17 (44.7\%). The largest percentage of respondents found themselves in the category of 35-44 years and had a high degree of lack of sense of personal achievement (Figure 2). Respondents involved in a community-based, married or domestic partnership, study had the most commonly inferior degree of personal achievement 16 (48.5\%), while those not had a low and high degree of personal achievement 9 (47\%).

High emotional exhaustion was present in 65 (85.5\%), showed non-significant difference in the degree of emotional exhaustion in relation to gender $(p=0.155)$. All age ranges had an equally high degree of emotional exhaustion. In the youngest range, as many as $94.7 \%$ of respondents have a high level of emotional exhaustion similar to those in the 35-44 age group of $90.3 \%$. A significant difference $(\mathrm{p}=0.042)$ was observed in respondents who do not had children, to be subjected to higher emotional exhaustion.

\section{DISCUSSION}

DMBI is the most commonly used instrument for testing burnout, instrument is designed for scientific purposes but is often used in practice [14]. According to the author MBI-HSS syndrome observed in three separate aspects of depersonalization, emotional exhaustion and lack of personal achievements, the same is not provided to connect them in a common score [15]. The purpose of this study was to evaluate the association of socio-demographic variables with the presence of the burning syndrome in the examined population of the physician to analyze some of the risk factors related to the work that could cause burning syndrome, which was done using the MBI-HSS questionnaire for which rights of use are purchased in Serbian language. In general, our results are similar to studies conducted in the US, Spain and Brazil $[13,16,17]$.

The "Emotional Exhaustion" scale possesses an adequate level of internal consistency (Cronbach $\alpha=0.728$ ) and the "Depersonalization" scale of the MBI questionnaire possesses an adequate level of internal consistency (Cronbach $\alpha=0.836$ ) and in relation to the values of other studies [18]. "Burnout" is measured through three scales of the Maslash Burning Questionnaire (MBI). "Burnout" is manifested through depersonalization, lack of personal achievement and emotional exhaustion. In the study, the highest percentage of respondents showed a low degree of depersonalization of $69.2 \%$, a high degree of personal accomplishment present in 24 (46\%) respondents and high levels of emotional exhaustion accounted for as much as $81 \%$. There is statistically significant weak negative correlation between age and degree of depersonalization $(\mathrm{rs}=-0.284 ; \mathrm{p}=0.041)$. Younger subjects have a higher degree of depersonalization. The majority of respondents live in a community 33 (63.46\%), and almost equally exposed to low depersonalization 23 (69.7\%) as those living alone (68.4\%). More than half of the respondents live in the community, with their families and children, so half of the cost of living, both family and personal, are on the burden of the respondents. The family provides great 
support and understanding and hence the preventive role and mechanism for overcoming stress [18].

There is a statistically significant weak negative correlation between the years of service and the degree of depersonalization. Respondents with a shorter service have a higher degree of depersonalization. Contemporary work is based on gender equality and as expected there is no statistically significant difference in the degree of lack personal accomplishment in relation to gender. In both genders occurs high degree of deficiency of personal accomplishment 38 (50.0\%), but 21 (55.3\%) female respondents slightly higher than male respondents 17 (44.7\%). Half of the respondents were very dissatisfied with personal achievement, the highest percentage of respondents being in the category of 35-44 years and having a high level of lack of personal accomplishment. High emotional exhaustion is present in both genders, although the difference between them is not a significant difference in the degree of emotional exhaustion compared to the gender $(\mathrm{p}=0.155)$, greater is the number of females (35) being emotionally exhausted compared to the male (30). The relationship between gender and emotional exhaustion is significant in a larger number of authors $[19,20]$, while the Pico put forward a similar situation as in our study [21]. All age groups have a high level of emotional exhaustion, a significant difference $(\mathrm{p}=0.042)$ was observed in subjects with or without children who are underweight for more emotional exhaustion.

\section{CONCLUSION}

1. More than half of the respondents live in community, with their family and have children.

2. Younger respondents have a higher level of psychological quality of life and have a higher degree of quality of life in social relationships. 3 . Respondents with children show a lower degree of emotional exhaustion.

4. Younger respondents have a higher degree of depression.

Based on the results of this study and literature, the burning syndrome is a medical condition, a psychological disorder that required to be followed through a multidisciplinary approach with modernly educated teams. In the future is expected that business tasks will be complicated so that personality and management adaptability will be of crucial importance for further professional development and progress.

\section{REFERENCES}

1. Schaufeli WB, Bunk BP. Burnout: An overview of 25 years of research and theorizing. The handbook of work and health psychology 2003; 2:282-424.

2. Freudenberger HJ. Staff burnout. J Soc Issues 1974; 30(1):159-65.

3. Weber A, Jaekel-Reinhard A. Burnout syndrome: a disease of modern societies? Occup Med 2000; 50(7): 512-7.

4. Maslach C, Jackson SE. The measurement of experienced burn-out. J Occup Behav 1981; 2(2): 99-113.

5. Sonnentag S. Burnout research: adding an offwork and day-level perspective. Work \& Stress 2005; 19(3):271-5.

6. Barrick KR. Burnout and job satisfaction of vocational supervisors. JAE 1989; 30(4): 35-41.

7. Salanova M, Llorens S. Curent state of research on burnout and future challenges. Papeles del Psicólogo 2008; 29(1):59-67.

8. Dyrbye LN, Thomas MR, Massie FS, Power DV, Eacker A, Harper W, Durning S, Moutier C, Szydlo DW, Novotny PJ, Sloan JA, Shanafelt TD. Burnout and suicidal ideation among U.S. medical students. Ann Intern Med 2008; 149(5):334-41.

9. Vuković MH, Vuković AD. Need for Reconceptualization of Professional Satisfaction and/or Work Effects in Healthcare Organizations. Hospital Pharmacology 2017; 4(3):573-80. Hospital Pharmacology - International Multidisciplinary Journal (www. hophonline.org )

10. Dedic G. Professional burnout. Vojnosanit Pregl 2005; 62(11):851-5.

11. Kompier M. The psychosocial work environment and health-what do we know and where should we go? Scand J Work Environ Health 2002; 28(1):1-4.

12. Evans SJ. Good surveys guide. British Medical Journal 1991; 302 (6772):302-3.

13. Maslach C, Jackson SE. The measurement of experienced burnout. Journal of organizational behavior. 1981:99-113.

14. Doulougeri K, Georganta K, Montgomery A. "Diagnosing" burnout among healthcare professionals: Can we find consensus? Cogent Medicine 2016 Dec $31 ; 3(1): 1$

15. Dyrbye LN, West CP, Shanafelt TD. Defining Burnout as a Dichotomous Variable. Journal of General Internal Medicine 2009;24(3):440. 
16. Maslach C, Jackson SE. MBI-Human Services Survey (MBI-HSS): The original measure that was designed for professionals in the human services. 1981; (http://www.mindgarden.com/117-maslachburnout-inventory)

17. The World Health Organization Quality of Life (WHOQOL) - BREF. World Health Organization. 2004; (http://www.who.int/substance_abuse/research_tools/en/english_whoqol.pdf)

18. Milenovic MS. Examination of the "burning syndrome at work" of anesthesiologists employed at the tertiary level of health care in Belgrade (Doctoral dissertation, University of Belgrade, Faculty of Medicine).

19. Amiri M, Khosravi A, Eghtesadi AR, Sadeghi Z, Abedi G, Ranjbar M, Mehrabian F. Burnout and its Influencing Factors among Primary Health Care Providers in the North East of Iran. PloS one 2016; 11(12).

20. Williams S, Zipp GP, Cahill T, Parasher RK. Prevalence of burnout among doctors of chiropractic in the Northeastern United States. Journal of manipulative and physiological therapeutics 2013; 36(6):376-84.

21. Piko BF. Burnout, role conflict, job satisfaction and psychosocial health among Hungarian health care staff: a questionnaire survey. International journal of nursing studies 2006; 43(3):311-8. 


\title{
Sindrom „sagorevanja“ kod lekara koji su zaposleni u Urgentnom Centru Kliničkog Centra Srbije
}

\author{
Aleksandra M. Bukumirovic $\dot{c}^{1}$, Sanja D. Totić-Poznanović́, \\ Ljiljana N. Marković-Denićs, Zoran M. Bukumirićc, Aleksandra N. Vlačićs, \\ Ratko M. Lasica ${ }^{6,7}$, Vladimir S. Radak ${ }^{1}$, Ana D. Šijački ${ }^{1,7}$ \\ ${ }^{1}$ Centar za naučnoistraživački rad, obrazovno-nastavnu delatnost i ljudske resurse, Klinički centar Srbije, \\ Beograd, Srbija \\ ${ }^{2}$ Klinika za psihijatriju, Klinički centar Srbije, Beograd, Srbija \\ ${ }^{3}$ Institut za epidemiologiju, Medicinskog fakulteta Univerziteta u Beogradu, Beograd, Srbija \\ ${ }^{4}$ Institut za medicinsku statistilu i informatiku, Medicinskog fakulteta Univerziteta u Beogradu, Beograd, \\ Srbija \\ ${ }^{5}$ Uprava za biomedicinu, Ministarstvo zdravlja Republike Srbije, Beograd, Srbija \\ ${ }^{6}$ Klinika za kardiologiju, Klinički centar Srbije, Beograd, Srbija \\ ${ }^{7}$ Medicinski fakultet Univerziteta u Beogradu, Beograd, Srbija
}

\section{KRATAK SADRŽAJ}

Uvod: Termin sagorevanje je često korišen za opis stanja ili mentalnog procesa sličnog vatrenom oružiju nakon pucanja ili gašenja istrošenih sveća.

Cilj: Cilj istraživanja je da se oceni odnos između sociodemografskih činilaca sa prisustvom sindroma sagorevanja kod ispitanika.

Metod: Istraživanje je sprovedeno kao studija preseka, tokom maja-juna meseca 2017. i februara-marta 2018. u Urgentnom centru Kliničkog Centra Srbije. Ispitani su lekari, zaposleni puno radno vreme, koji su ljubazno prihvatili da popune anonimno upitnike. Za subjektivnu procenu percepcije zdravlja korišćena je srpska verzija Maslašovog upitnika za procenu sindroma sagorevanja na poslu „Maslach Burnout Inventory-Human Services Survey (MBI)“.

Rezultati: U proceni stepena sagorevanja MBI-HSS na srpskom jeziku ukupno 76 ispitanika je popunilo anketu, najzastuljenija (reprezentativnija) je kategorija 35-44 godina staristi sa $40.8 \%$ ispitanika. Ispitanici najčešće žive u zajednici $52.6 \%$ od svih a 48.7\% imaju decu. $75 \%$ ispitanika pokazuje nizak stepen depersonalizacije. Nađena je značajna negativna korelacija između godina radnog staža i depersonalizacije. Oba pola $(50.0 \%$ ispitanika) su pokazala visok stepen nedostatka ličnog dostignuća, pritom neznatno više ispitanici ženskog pola $55.3 \%$ nego muškog pola $44.7 \%$. Visok stepen emocionalne iscrpljenosti je prisutan kod $85.5 \%$ i nema značajne razlike među polovima. Značajna razlika u emocionalnoj iscrpljenosti je primećena kod ispitanika bez dece u smislu visoke emocionalne iscrpljenosti.

Zaključak: Sindrom sagorevanja bi tebao da razmatra tim sastavljen od eksperata (iz oblasti psihijatrije, medicine rada i epidemiologije) kako bi odredili do koje mere je sagorevanje vezano za posao, kako da se prevenira i ublaže posledice. Ispitanici sa manjim radnim stažom imaju veći stepen depersonalizacije i ispitanici bez dece viši stepen emocijonalne iscrpljenosti.

Ključne reči: sindrom sagorevanja, stres, lekari 